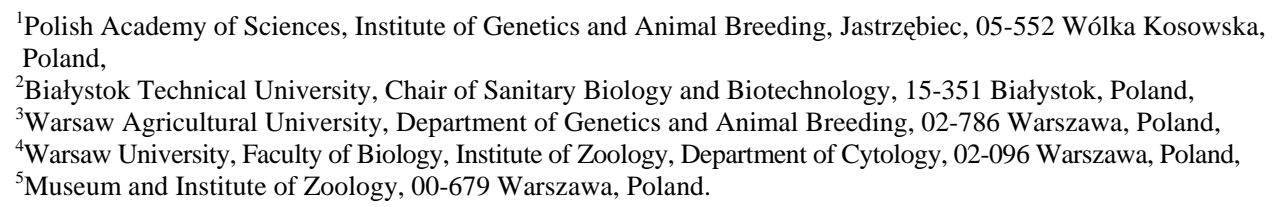

\title{
Skeletal muscle and liver protein degradation in mice divergently selected for low and high body weight over 108 generations
}

\begin{abstract}
Experiment was carried out on 111 and 13-14 weeks old mice divergently selected for low (L) and high (C) body weight over 108 generations. In leg muscle and liver cathepsin D (CatD) was determined as pepstatin sensitive activity (PSCatD), and as pepstatin-insensitive (PIA) and leupeptin-insensitive (LIA) acid autolytic activities (AAA) were measured. In leg muscle and liver all measured activities were higher in $\mathrm{L}$ as compared to $\mathrm{C}$ and control $(\mathrm{K})$ mice. The percent of inhibition of LIA was lower in L then C mice in both examined tissues. In the leg muscles, in L mice protein catabolism was mostly influenced by CatD, but in the liver CatD was mostly active in $\mathrm{K}$ mice. CatD, PSCatD, AAA and LIA in leg muscle of $\mathrm{L}$ mice as compare to $\mathrm{K}$ were higher in female (F) by $68 \%, 68.5 \%, 91.3 \%$ and $94.5 \%$, respectively, and in male (M) mice by $43.4 \%, 54 \%, 47.1 \%$ and $64 \%$, respectively. The percent of inhibition by leupeptin in AAA was higher in C mice by $61.9 \%$ in $\mathrm{F}$ and by $40 \%$ in $\mathrm{M}$ mice. In the liver, PIA was higher by about $45 \%$ in $\mathrm{L}$ and by $28.5 \%$ in $\mathrm{C}$ mice as compare to $\mathrm{K}$ ones. There were about $36 \%$ of $30.00-39.99 \mu \mathrm{m}$ muscle fibrils in $\mathrm{M}$ mice and in males of $\mathrm{L}$ group 40.00-49.99 $\mu \mathrm{m}$ fibrils appeared at 25\% (absent in 3 weeks mice). In female, all measured fibril diameters were in higher percent in $\mathrm{L}$ than in $\mathrm{C}$ group. RNA variables were higher by about 25\% (in average) in $\mathrm{C}$ as compare to $\mathrm{K}$ and $\mathrm{L}$ groups. Functional cell size (FCS) was lowered in L and C group as compared to $\mathrm{K}$ by about $10 \%$ (in average). These results indicate on faster proteins turnover in $\mathrm{L}$ than in $\mathrm{C}$ group of mice.
\end{abstract}

Key Words: mice; long term selection, body weight, proteolytic enzyme activity, muscle DNA-RNA, liver DNA-RNA, fibre size

\section{Zusammenfassung}

Titel der Arbeit: Skelettmuskel und Leberproteinveränderungen nach 108 Selektionsgenerationen auf niedrige und hohe Körpergewichte bei Mäusen

Mäuse wurden 108 Generationen auf ein niedrigeres (L) bzw. höheres (C) Körpergewicht selektiert und mit einer Kontrollgruppe $(\mathrm{K})$ verglichen. Die vorgelegten Untersuchungen zu Veränderungen an Skelettmuskeln bzw. die Leberproteinveränderungen erfolgten an 111 Tieren im Alter von 13-14 Wochen. Die Catepsin D (CatD) Aktivitäten in beiden untersuchten Geweben reagierten als Pepstatin-Cathepsin D (PSCatD). Ebenfalls bestimmt wurde die autolytische Aktivität (AAA) hinsichtlich Pepstatin (PIA) und Leupeptin (LIA). Die im Schenkelmuskel und der Leber gemessenen Aktivitäten waren für die L-Gruppe höher als bei den verglichenen C- und Kontrollgruppen.

Die prozentuale Hemmung der LIA-Werte war in beiden Geweben in der L-Gruppe niedriger als in der C-Gruppe. Im Schenkelmuskel der L-Mäuse wurde der Proteinkatabolismus überwiegend durch die CatD beeinflusst. In der Leber war die CatD aktiver in der K-Gruppe. Die Aktivität von CatD, PSCatD, AAA und LIA war im Schenkelmuskel der L-Mäuse höher als bei den K-Mäusen. Bei den weiblichen Tieren der L-Gruppe waren die entsprechenden Messwerte um 68,0\%, 68,5\%, 91,3\% bzw. 94,5\% höher als bei der Kontrollgruppe. Bei den männlichen Tieren der gleichen Gruppe erhöhten sich die analogen Werte jedoch nur um 43,3\%, 54,0\%, 47,1\%, bzw. 64,0\%. Die prozentuale Hemmung der LIA bezüglich der AAA war in der C-Gruppe höher (Weibchen 61,9\%; Männchen 40,0\%). In der Leber war die Aktivität der PIA bei der L-Gruppe um 45,0\% und bei der C-Gruppe um 28,5\% höher als bei der Kontrollgruppe. Im Alter von drei Monaten fanden sich in der K-Gruppe bei den männlichen Mäusen 36,0\% mehr Fibrillen in der Muskelfaser mit einem Durchmesser von 30,00-39,99 $\mu \mathrm{m}$, bei der L-Gruppe nur 
25,0\% mehr Fasern mit einem Durchmesser von 40,00-49,99 $\mu$ m, die bei den Mäusen im Alter von drei Wochen fehlten. Bei den Weibchen lagen alle Durchschnittswerte der Muskelfasern bei der L-Gruppe höher als bei der CGruppe. Die Muskel-RNA Variablen waren in der C-Gruppe durchschnittlich um 25,0\% höher als bei den L- und KGruppen. Die FCS wurde um rund 10,0\% niedriger in den L- und C-Gruppen im Vergleich zur Kontrolle festgestellt. Die Versuchsergebnisse zeigten einen schnelleren Eiweißumsatz bei den Mäusen der L- als in der C-Gruppe.

Schlüsselwörter: Maus, Langzeitselektion, Körpergewicht, Proteinaktivität, Muskel DNA-RNA, Muskeldurchmesser

\section{Introduction}

Animal growth is a function of genetic and nutritional factors and it is mostly reflected in the growth of muscle fibril diameter and changes in fibril types (REHFELD and BÜNGER, 1990; FIEDLER et al., 1998). Accretion of muscular tissue is a dynamic process (GRANT and HELFERICH, 1991) and is controlled by a delicate balance between protein synthesis and degradation. These changes in the kinetics on both sides of the equilibrium will result in an increased or a decreased muscle' growth, thus changing the final muscle weight gain (SHMIDT et al., 2000) which is strongly connected with the remodeling of the fibrils.

There are some evidences concerning remarkable sensitivity of the overall rate of protein degradation in muscle and liver to nutritional factors (MILLWARD et al., 1980, 1981). In some physiological and mainly pathological states muscle growth is determined solely at the catabolic side (eg. muscular atrophy after denervation and tenotomy, chemically and hormonally induced changes) (KÜCHENMEISTER et al., 2001; KÜCHENMEISTER and KUHN, 2003) The process of protein catabolism involves a nonlysosomal and lysosomal route of intracellular protein catabolism. The calciumdependent neutral proteolytic system consisting of $\mu$ - and m-calpain and their natural inhibitor calpastatin, do not degrade any of the major myofibrillar proteins like myosin and actin (THOMPSON and PALMER, 1998; GOLL et al., 1998; JOHARI et al., 1993). The whole process of protein degradation is believed to be initiated by these enzymes, which remove at the beginning the Z-disk of myofibrills (BELCASTRO et al., 1998). Lysosomal proteinases cathepsin D and cathepsin B - under physiological conditions are compartmentalized inside the lysosomes, where they act as a cellular disposal system for damaged and otherwise obsolete proteins and peptides. These enzymes exhibit their maximal proteolytic activities at low $\mathrm{pH}$ and are capable of degrading myosin and actin and a large number of other myofibrillar proteins into relatively small fragments (MIKAMI et al., 1987). They are also capable of further breaking down degradation products of other proteolytic systems. Apart of the calpains and cathepsins, most cells have a multicatalytic proteinase system (MCP) that can be involved in the initial step of myofibrillar degradation and disassembly of these proteins. ATP-ubiquitin (Ub)dependent pathway is responsible for the degradation of short-lived and abnormal proteins and myofibrils disassembling (THOMPSON and PALMER, 1998).

There is a lot of evidence, that rate of protein degradation varies in the same way as activity of cathepsin D in various rat (MILLWARD et al., 1981) and chicken muscle (LAURENT et al., 1978; ROSOCHACKI, 1985). GOLDSPINK and LEWIS (1985) demonstrated that cathepsin $\mathrm{B}$ could be the rate of protein degradation indicator. By measuring the activity of cathepsin $\mathrm{D}$ and thiol proteinases one can easily follow changes in the protein degradation rate.

The main aim of this study was to examine the kind of changes in the activity of the degrading system involved in the degradation of the metabolized proteins in skeletal 
muscle of mice and their influence on the remodeling of the fibrils. The experiment has been also designed to examine the influence not only of the selection for body weight but also of the sex of mice on the activities of some lysosomal proteolytic enzymes, RNA, DNA and protein content as well as the fibril size in leg muscle (and liver) of mice. These measurements may help determine whether mice selected divergently over 108 generation for body weight can be used as animal models for the study of skeletal muscle protein turnover.

\section{Material and methods}

The experiment was done on mice divergently selected for low (L, 42 mice) and high (C, 39 mice) body weight over 108 generations compared to control (K, 30 mice), and divided into male $(\mathrm{M})$ and female $(\mathrm{F})$ groups. These lines of animals were derived from out-bread strains by crossing four in-bread lines: A/St, BN/a, BALB/c and C57BL/6Jn. Animals were kept in Experimental Mice Farm in Warsaw Agriculture University and fed with standard food ad libitum with access to water and kept up to 98 days of life. After 14 hours of fasting, the mice were weighted, slaughtered and liver and leg muscle were removed immediately weighted and placed on ice, then frozen at $-70^{0} \mathrm{C}$ for subsequent analysis of DNA, RNA, protein content, as well as lysosomal enzymes activity.

Gastrocnemius muscle was dissected from 6 mice in each experimental group for fibril diameter estimation. After weighting, the muscles were immersed in isopentane (Merck) cooled by liquid nitrogen. Frozen muscles were kept in $-80^{\circ} \mathrm{C}$ until required. The muscles were cut on microton in $-25^{\circ} \mathrm{C}$ getting $10 \mu \mathrm{m}$ thick slices. After hydration, the slices were stained with acidic Harris' hemotoxyline and after that with $1 \%$ of eosin in water $(\mathrm{BDH})$. The stain was washed out and the slices of tissue were dehydrated with alcohol and kept in ethalanol (Merck). Slices were photographed five times in microscope Nicon and ACT-1 program; the diameter of fibrils was measured by Lucia G program. The data were elaborated by Excel program.

Sample was taken and processed for proteolytic enzyme activity analysis: lysosomal cathepsin D, PSCatD, acid autolytic activity with pepstatin and leupeptin as inhibitors. Pepstatin is an inhibitor of cathepsin D while leupeptin inhibits thiol proteinases. Frozen tissue samples were homogenized in 10 vol. of cold $0.1 \%$ triton x-100 in water on ice. The samples were incubated at $45^{\circ} \mathrm{C}$ in $500 \mathrm{mM}$ formic buffer, $\mathrm{pH}=3.75$, for $1 \mathrm{hr}$, and the reaction was stopped by the addition of trichloracetic acid (TCA). The activity of cathepsin D was determined as PSCatD towards $1 \%$ hemoglobin as described previously (ROSOCHACKI, 1985). PIA and LIA activities were measured in the presence of $1 \mathrm{mM}$ $\mathrm{Mg}^{++}$(only autolytic activity with pepstatin was measured in $\mathrm{pH}$ of buffer 3.25). All proteolytic activities were measured using a modified alkaline cooper reagent, with tyrosine as a standard. Enzyme activity was expressed as $\mu \mathrm{g}$ of tyrosine per mg of protein per $1 \mathrm{hr}$.

Muscle and liver DNA and RNA concentrations were determined in approximately 100 mg of samples according to the procedure of MUNRO and FLECK (1966). Protein was determined according to procedure of LOWRY et al., (1951). The same procedure was used to determine proteolysis products dissolved in $3 \%$ TCA as well as for the correction of RNA estimations.

Data were analyzed by analysis of variance according to the models:

for body weight and weight of legs and liver (Table 1): $y_{i j}=\mu+\alpha_{i}+\beta_{j}+(\alpha \beta)_{i j}+e_{i j}$ 
for weight of muscle for right leg (Table 1): $y_{i j k}=\mu+\alpha_{i}+\beta_{j}+(\alpha \beta)_{i j}+b\left(x_{i j k}-x\right)+e_{i j k}$ for proteinase activities and RNA and DNA variables (Tables 2-5):

$\mathrm{y}_{\mathrm{ijkl}}=\mu+\mathrm{T}_{\mathrm{i}}+\mathrm{M}_{\mathrm{j}}+\mathrm{P}_{\mathrm{k}}+\mathrm{e}_{\mathrm{ijk} \mathrm{k}}$.

Where: $\mathrm{y}_{\mathrm{ij}}, \mathrm{y}_{\mathrm{ijk}}, \mathrm{y}_{\mathrm{ijkl}}-$ an observation; $\mu$ - overall mean; $\alpha_{\mathrm{i}}$ - fixed effect of $\mathrm{i}$-th sex; $\beta_{\mathrm{j}}$ fixed effect of $\mathrm{j}$-th line of mice; $(\alpha \beta)_{\mathrm{ij}}$ - interaction between group of mice and sex; $\mathrm{b}$ regression coefficient; $\mathrm{e}_{\mathrm{ij}}, \mathrm{e}_{\mathrm{ijk},} \mathrm{e}_{\mathrm{ijkl}}$ - random error; $\left(\mathrm{x}_{\mathrm{ijk}}-\mathrm{x}\right)$ - regression for weight of muscle; $T_{i}$ - fixed effect of i-th of body weight; $M_{j}$ - fixed effect of $j$-th of tissue; $P_{k}-$ fixed effect of k-th sex of mice.

When significant differences among groups were detected, the t-test was used to compare significant differences between the groups. To check the statistical differences between percentage of inhibition, the square root transformation was done, and analysis of variance was performed.

\section{Results}

The differences between body weight, and weight of leg muscle of $\mathrm{L}$ and $\mathrm{C}$ mice were about $83 \%$ in $\mathrm{M}$ and about $71 \%$ in $\mathrm{F}$, and in the weight of liver $90 \%$ and $100 \%$, respectively (Table $1, \mathrm{~F}_{1,56}=410.54, \mathrm{p} \leq 0.001$ ). All variables were always higher in male as compared to female group $(\mathrm{p} \leq 0.01)$.

Table 1

Body weight of mice and weight of muscle and liver in mice at 98 days selected for low (L) and high (C) body weight for 108 generation (K control) (Körpergewicht sowie Muskel- und Lebergewicht von Mäusen, selektiert auf hohes und niedriges Körpergewicht nach 108 Generationen)

\begin{tabular}{l|llll|lll}
\hline & \multicolumn{3}{|c|}{ MALE } & \multicolumn{3}{c}{ FEMALE } \\
& $\mathrm{K}$ & $\mathrm{L}$ & $\mathrm{C}$ & $\mathrm{K}$ & $\mathrm{L}$ & $\mathrm{C}$ \\
\hline Body weight (g) & $31.08 \mathrm{~A}$ & $22.20 \mathrm{~A}^{* *}$ & $40.36 \mathrm{~A}^{* *}$ & $26.71 \mathrm{~A}$ & $19.08 \mathrm{~A}^{* *}$ & $32.54 \mathrm{~A}^{* *}$ \\
& \pm 3.54 & \pm 4.04 & \pm 2.80 & & \pm 2.30 & \pm 2.58 & \pm 2.39 \\
Weight of left leg (g) & $2.10 \mathrm{~B}$ & $1.51 \mathrm{~B}^{* *}$ & $2.72 \mathrm{~B}^{* *}$ & $1.85 \mathrm{~B}$ & $1.32 \mathrm{~B}^{* *}$ & $2.29 \mathrm{~B}^{* *}$ \\
& \pm 0.32 & \pm 0.31 & \pm 0.32 & & \pm 0.21 & \pm 0.25 & \pm 0.14 \\
Weight of right leg (g) & $2.10 \mathrm{C}$ & $1.51 \mathrm{C}^{* *}$ & $2.78 \mathrm{C}^{* *}$ & & $1.79 \mathrm{C}$ & $1.28 \mathrm{C}^{* *}$ & $2.23 \mathrm{C}^{* *}$ \\
& \pm 0.34 & \pm 0.36 & \pm 0.33 & & \pm 0.20 & \pm 0.23 & \pm 0.17 \\
Weight of muscle & $1.46 \mathrm{~d}$ & $1.04 \mathrm{Dd}^{*}$ & $1.93 \mathrm{Dd}^{* *}$ & $1.20 \mathrm{~d}$ & $0.86 \mathrm{Dd}^{*}$ & $1.48 \mathrm{Dd}^{* *}$ \\
For right leg (g) & \pm 0.28 & \pm 0.27 & \pm 0.27 & \pm 0.20 & \pm 0.19 & \pm 0.16 \\
\hline Weight of liver (g) & $1.62 \mathrm{E}$ & $1.16 \mathrm{E}^{*}$ & $2.20 \mathrm{E}^{* *}$ & $1.52 \mathrm{E}$ & $0.94 \mathrm{E}^{*}$ & $1.89 \mathrm{E}^{* *}$ \\
& \pm 0.09 & \pm 0.19 & \pm 0.29 & & \pm 0.23 & \pm 0.15 & \pm 0.32 \\
\hline
\end{tabular}

* $(\mathrm{p} \leq 0.05)$ and $* *(\mathrm{p} \leq 001)$ - statistical differences between $\mathrm{F}$ and $\mathrm{M}$ in groups $\mathrm{L}$ and C. Letters - small or capitals, encode statistical differences ( $\mathrm{p} \leq 0.05$ or $\mathrm{p} \leq 0.01$ ) between: groups $\mathrm{L}, \mathrm{C}$ and $\mathrm{K}$.

\section{Muscle}

Protein concentration was higher in female than in male mice of $\mathrm{K}$ and $\mathrm{C}$ groups, and there were significant differences between female and male group $(\mathrm{p} \leq 0.01)$ in $\mathrm{L}$ and $\mathrm{C}$ mice. Also, some statistical differences were found in each sex between examined groups of mice (Table 2).

Cathepsin D activity was significantly different between sexes in $\mathrm{L}$ and $\mathrm{C}$ groups $(\mathrm{p} \leq 0.05$ and $\mathrm{p} \leq 0.01$, respectively, Table 2 ) and it was also the effect of group in male and female. The highest changes were noticed between $\mathrm{K}$ and $\mathrm{L}$ groups in both examined sexes, being higher in L by $68 \%$ in $\mathrm{F}$ and by $43 \%$ in $\mathrm{M}$ mice. PSCatD was also changed in the same extent between groups of mice in both sexes, being higher by $68.5 \%$ in $\mathrm{F}$ and $54 \%$ in $\mathrm{M}$ mice of $\mathrm{L}$ group as compare to $\mathrm{K}$ mice. This is supported also by some differences found out in AAA, PIA and LIA between examined groups and between males and females in AAA in L and in PIA in C groups of mice ( $\mathrm{p} \leq 0.05$ and $\mathrm{p} \leq 0.01$, respectively). Percent of cathepsin D inhibition by pepstatin was statistically different between $\mathrm{L}$ and $\mathrm{C}$ 
males, being lower in male of $\mathrm{C}$ group $(\mathrm{p} \leq 0.05)$ and the inhibition in AAA by pepstatin was also statistically different between females and males $(\mathrm{p} \leq 0.01)$ in $\mathrm{K}$ group, and between examined groups in males (Table 2).

Table 2

Mean values of proteinase activities in leg muscle in control (K) and lines selected for low (L) and high (C) body weight at mice selected over 108 generations (in $\mu \mathrm{g}$ of tyrosine/mg of protein) (Durchschnittswert der Proteinase- Aktivitäten im Schenkelmuskel in den Mäusegruppen selektiert auf höheres und niedrigeres Körpergewicht nach 108 Generationen)

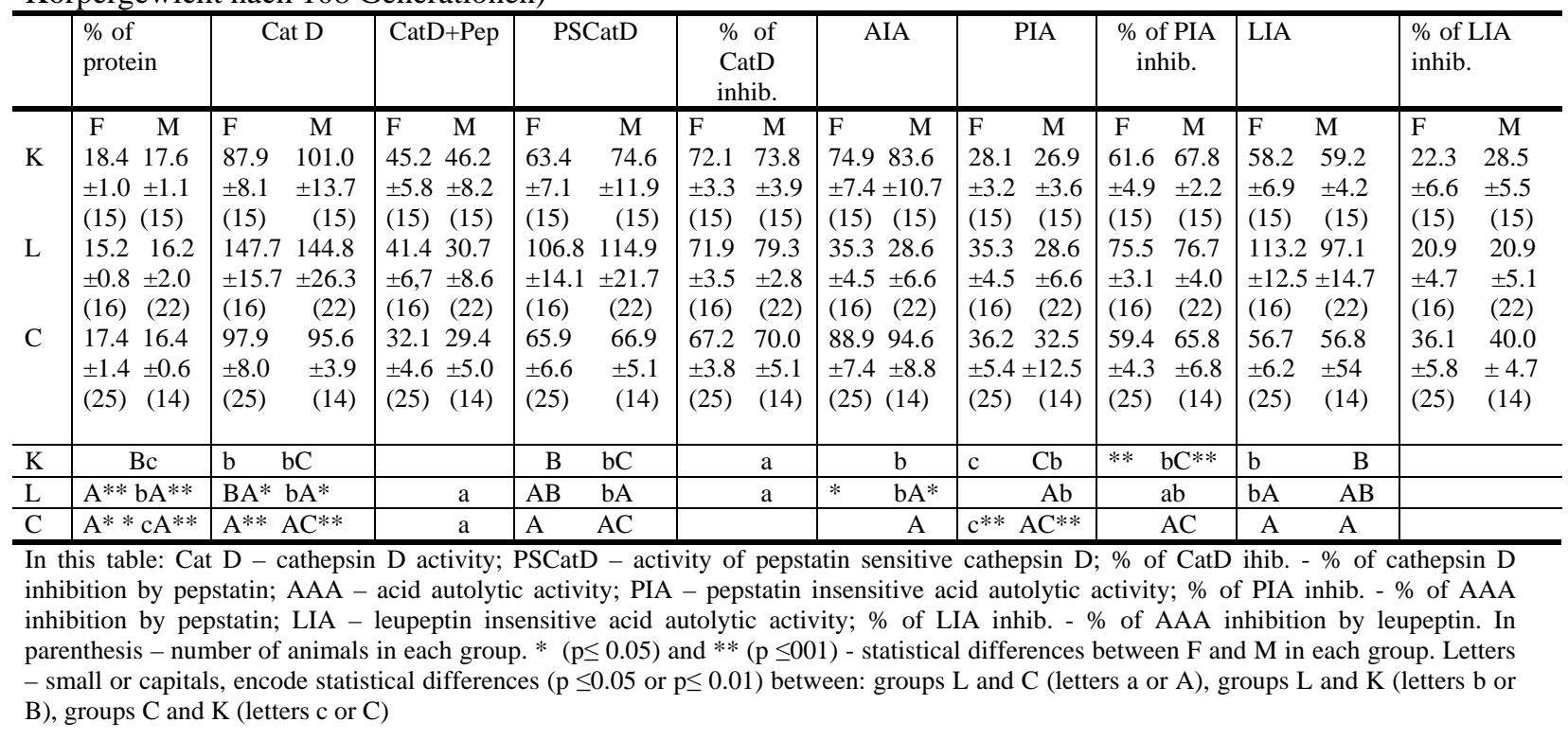

Significant differences were observed in RNA content per g of muscle between sexes in $\mathrm{L}$ and $\mathrm{C}$ groups and between groups in each sex (see Table 4). The content of RNA was higher in $\mathrm{C}$ group by about $25 \%$ (in average) as compare to $\mathrm{K}$ and $\mathrm{L}$ groups, and was always lower in $\mathrm{M}$ than in $\mathrm{F}$ mice (by about $10 \%$ ). RNA:protein ratio was changed substantially between mice of different sexes in L group $(p \leq 0.01)$, and there were also statistical differences between $K, L$ and $C$ group in both sexes $(p \leq 0.05)$. This ratio was also higher in $\mathrm{C}$ group (in average by $22.5 \%$ ) as in $\mathrm{L}$ or $\mathrm{K}$ groups. In the muscle, the selection for body weight caused small changes in DNA content - by $12.6 \%$ and $16.7 \%$ increase in $\mathrm{F}$ mice and by $8.6 \%$ and $16.2 \%$ in $\mathrm{M}$ mice in $\mathrm{L}$ and $\mathrm{C}$ lines as compare to $\mathrm{K}$, respectively (Table 4). DNA content was always lower in $\mathrm{M}$ as compare to $\mathrm{F}$ mice in all groups by about $20 \%$. Functional cell size (FCS) decreased in experimental groups of both sexes of mice as compare to control mice, and some statistical differences between sexes were noticed in control and line $\mathrm{C}$ of mice. FCS was always higher in $\mathrm{M}$ as compare to $\mathrm{F}$ mice in all groups by about $30 \%$ and was lowered by about $10 \%$ (in average) in $\mathrm{L}$ and $\mathrm{C}$ groups as compare to $\mathrm{K}$ group of mice. RNA:DNA ratio was changed between $\mathrm{F}$ and $\mathrm{M}$ in each group of mice (statistical differences) and was always lower in female as compared to male in each group.

Morphological observation showed the differences between histological horizontal crosses in the muscles of examined mice (Fig.). Female of $\mathrm{C}$ group had much less muscle fibrils of $49.99 \mu \mathrm{m}$ diameter than female of $\mathrm{L}$ group, but much more of 50.00-59.99 $\mu \mathrm{m}$. Also, in muscle of $\mathrm{C}$ mice the fibrils of above $80.00 \mu \mathrm{m}$ appeared in higher percent than in L group of female. In male mice, about $36 \%$ of fibrils were between 30.00-39.99 $\mu \mathrm{m}$. No fibrils of $10.00 \mu \mathrm{m}$ or less diameter were found in both groups of male mice. 
Table 4

Mean values of RNA and DNA variables in leg muscle in control (K) and lines selected for low (L) and high (C) body weight of mice selected over 108 generations (Durchschnittswert der RNA- und DNA-Variablen im Schenkelmuskel in den Mäusegruppen selektiert auf höheres und niedrigeres Körpergewicht nach 108 Generationen)

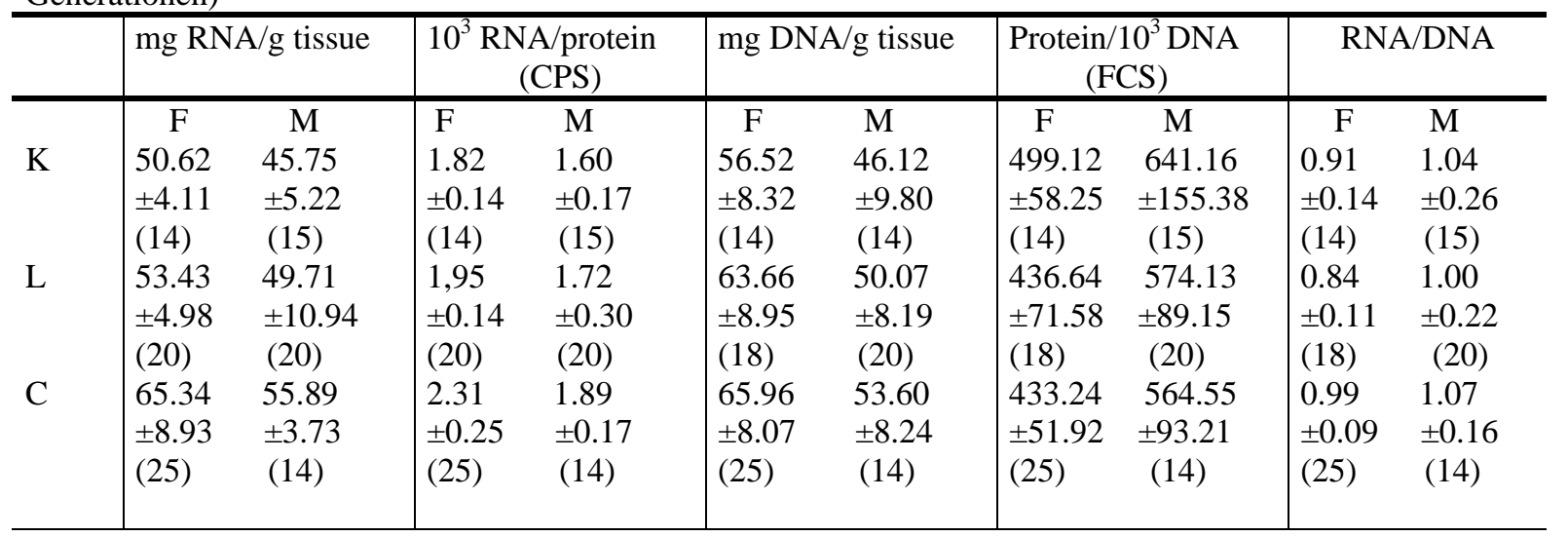

Statistical differences

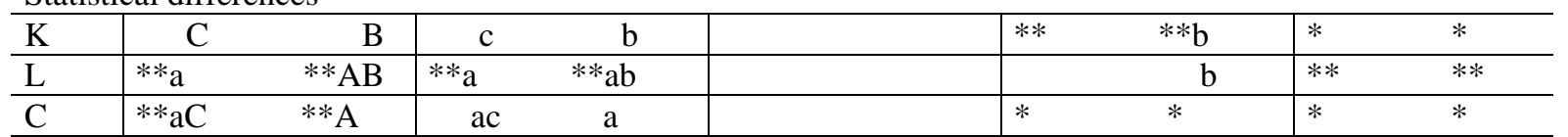

In this table: CPS - capacity for protein synthesis; FCS - functional cell size. In parenthesis - number of animals in each group. ${ }^{*}$ (p $\leq 0.05$ ) and $* *(p \leq 001)$ - statistical differences between $\mathrm{F}$ and $\mathrm{M}$ in each group. Letters - small or capitals, encode statistical differences (p $\leq 0.05$ or $\mathrm{p} \leq 0.01$ ) between: groups L and C (letters a or A), groups L and K (letters b or B), groups C and K (letters c or C)

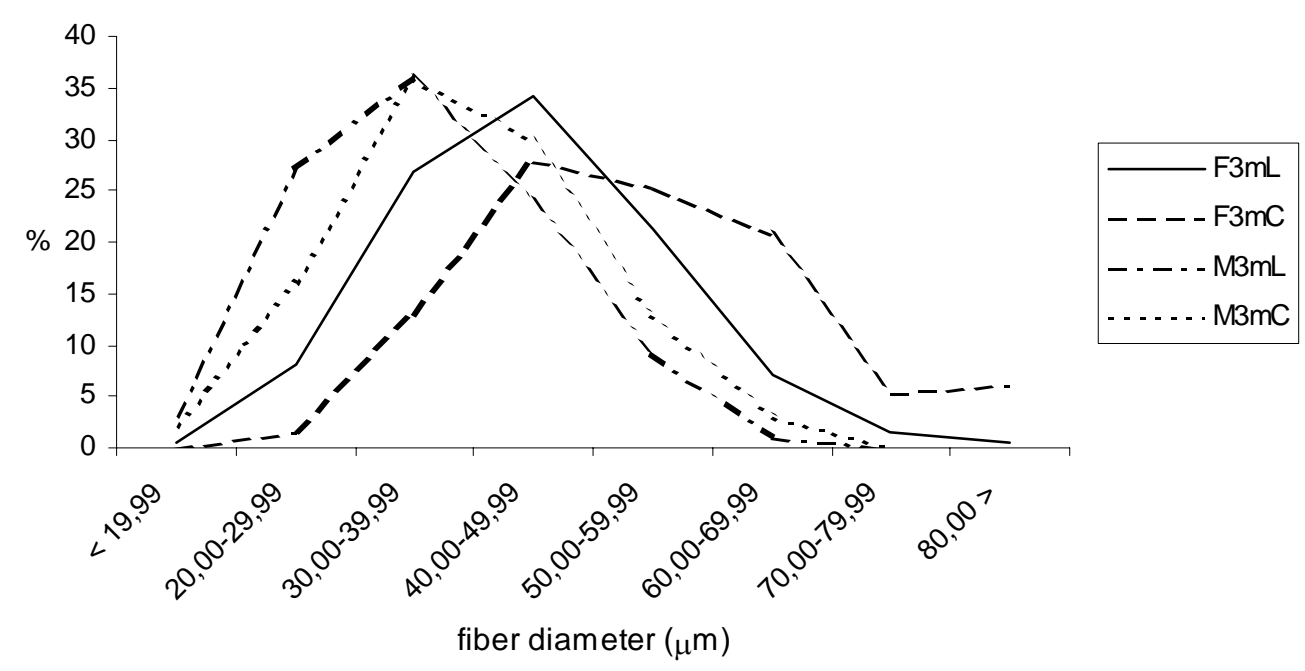

Fig.: Fiber diameter $(\mu \mathrm{m})$ of skeletal muscle of male $(\mathrm{M})$ and female $(\mathrm{F})$ mice from light $(\mathrm{L})$ and heavy $(\mathrm{C})$ lines divergently selected for body weight over 108 generations. 3m - three months (Durchmesser der Muskelfasern für die Weibchen (F) und Männchen (M) in den L- und C- Mäusegruppen selektiert auf das höhere und niedrigere Körpergewicht nach 108 Generationen, 3m - drei Monate alt)

\section{Liver}

There were no statistical differences in protein concentration in liver between examined groups of mice. Some significant changes were found between groups of mice in: CatD, CatD+Pep, PSCatD, PIA, \% of CatD inhibition and \% of LIA inhibition in AAA (Table 3). Total cathepsin $\mathrm{D}$ activity was significantly different $(\mathrm{p} \leq 0.05)$ between males and females in $\mathrm{C}$ group of mice and between $\mathrm{L}$ and $\mathrm{C}$ and $\mathrm{K}$ and $\mathrm{L}$ in male mice ( $\mathrm{p} \leq 0.01$ and $\mathrm{p} \leq 0.05$, Table 3). PSCatD activity differed between groups of mice in F and M. Only PIA was significantly changed in females between groups K-L and L-C, being highest in L group. Percent of inhibition by pepstatin in cathepsin $\mathrm{D}$ was different between $\mathrm{K}, \mathrm{L}$ and $\mathrm{C}$ groups in $\mathrm{M}$ animals. The percent of 
inhibition by leupeptin in AAA was significantly changed between males and females in K group ( $\mathrm{p} \leq 0.01)$ and between males and females in $\mathrm{L}$ and $\mathrm{C}$ groups $(\mathrm{p} \leq 0.05$, Table 3 ).

Table 3

Mean values of proteinase activities in liver in control (K) and lines selected for low (L) and high (C) body weight of mice selected over 108 generations (in $\mu \mathrm{g}$ of tyrosine/mg of protein) (Durchschnittswert der Proteinase- Aktivitäten in der Leber in den Mäusegruppen selektiert auf höheres und niedrigeres Körpergewicht nach 108 Generationen)

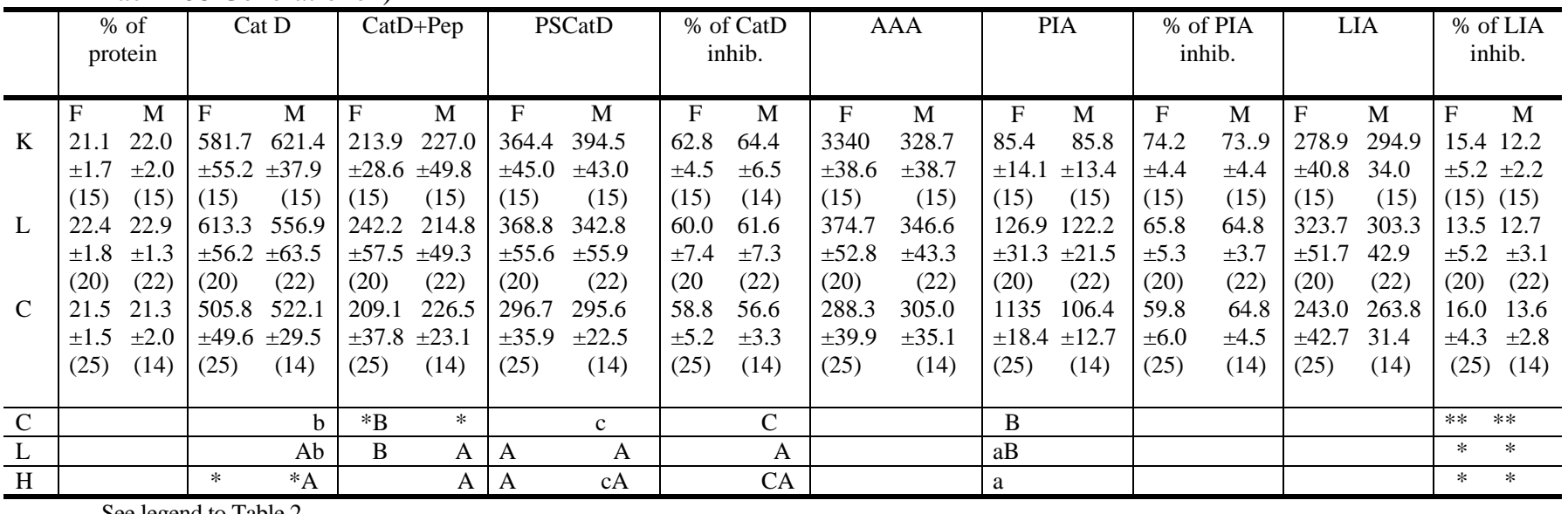

See legend to Table 2

RNA per g of liver differed statistically between males in $\mathrm{K}$ and $\mathrm{C}$ and $\mathrm{K}$ and $\mathrm{L}$ groups and between sexes in $K$ group ( $\mathrm{p} \leq 0.01$, Table 5 ). RNA/protein ratio was changed significantly between males and females in $\mathrm{K}(\mathrm{p} \leq 0.01)$, but between groups of $\mathrm{L}$ and $\mathrm{C}$ in F mice $(\mathrm{p} \leq 0.05)$ and between $\mathrm{K}$ and $\mathrm{C}$ and $\mathrm{K}$ and $\mathrm{L}$ in $\mathrm{M}$ mice $(\mathrm{p} \leq 0.01$, Table 5$)$. DNA per $g$ of liver as well as protein/DNA ratio were not different between groups of animals. Statistical difference was in protein/DNA ratio between sexes in $\mathrm{K}$ group of mice $(\mathrm{p} \leq 0.01$ ), and was always higher in $\mathrm{M}$ as compared to $\mathrm{F}$ mice. The RNA:DNA ratio was significantly different between $F$ and $M$ in $K(p \leq 0.05)$ and $C(p \leq 0.01)$ groups of mice and was always higher in male as compared to female mice by about 31\%, $18 \%$ and 39 $\%$ in $\mathrm{K}, \mathrm{L}$ and $\mathrm{C}$ groups, respectively. These differences were much higher then those found in leg muscles.

Table 5

Mean values of RNA and DNA variables in liver in control (K) and lines selected for low (L) and high (C) body weight of mice selected over 108 generations (Durchschnittswert der RNA- und DNA-Variablen in der Leber in den Mäusegruppen selektiert auf höheres und niedrigeres Körpergewicht nach 108 Generationen)

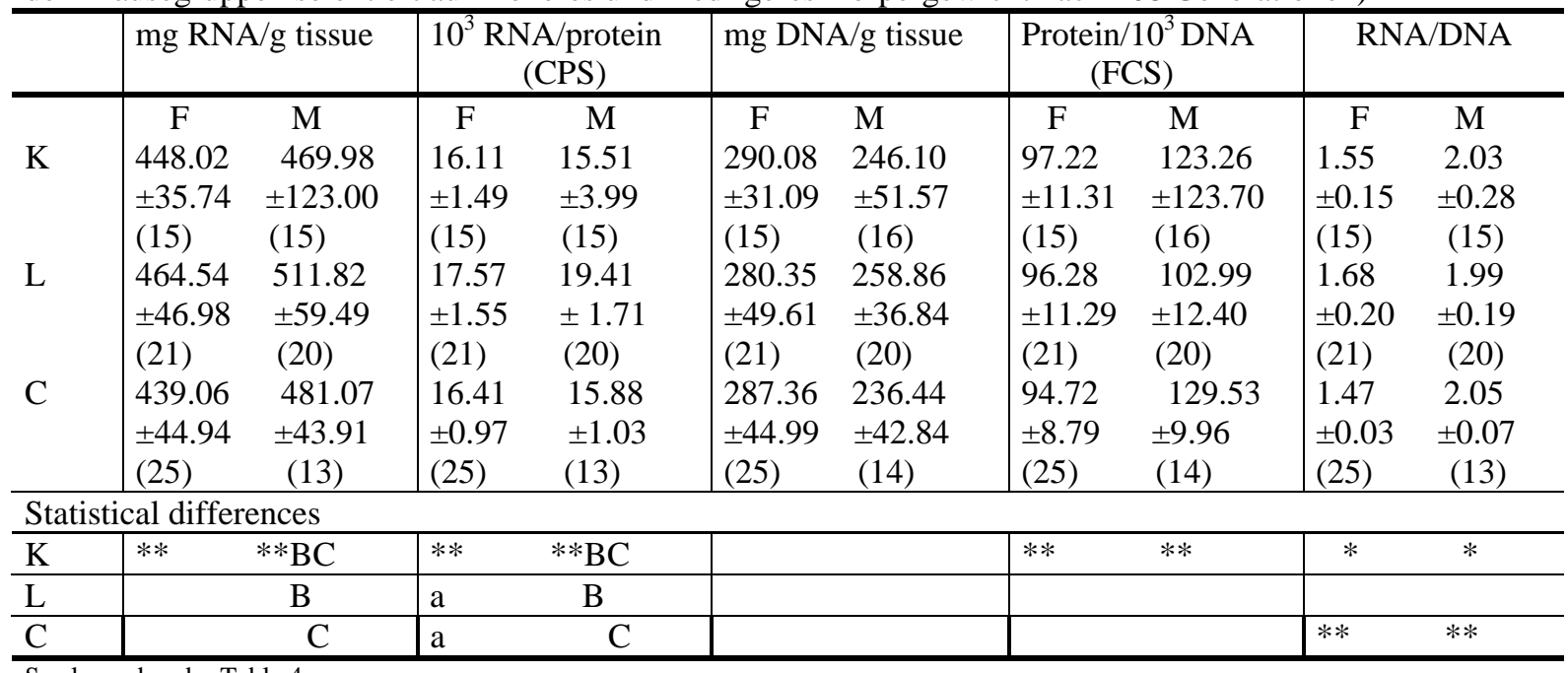

See legend under Table 4. 


\section{Discussion}

The purpose of this study was to determine whether mice selected for lower (L) and higher (C) body weight over 108 generations could be used as an animal model to study skeletal muscle protein turnover. In our previous experiment on mice selected over 90 generation for low and high body weight we found differences in puberty, in aging between the lines; small mice lived longer than the heavy ones (WIRTHDZIĘCIOŁOWSKA et al., 1996, 1997, 2000). The effect of sex in such a divergently selected mice, was also taken into consideration. So far, no muscle or liver protease data exist, to our knowledge, on such a material, although in our hands there are some data concerning mentioned above measurements performed on mice differently fed or under the influence of stress (ROSOCHACKI and PIEKARZEWSKA, 1988; ROSOCHACKI, 1989).

The greater DNA (in F) and RNA (in F and M) and lower protein concentration in L and $\mathrm{C}$ mice as compared to K (some statistical differences, Tables 2 and 4) imply a difference in the growth curves of examined mice. The animals were sacrificed at $98^{\text {th }}$ day of life and reached the weight of $22.20 \mathrm{~g}$ in $\mathrm{L}$ males and $19.08 \mathrm{~g}$ in $\mathrm{L}$ females and the $\mathrm{C}$ mice were almost twice as heavy $\left(\mathrm{F}_{1,56}=410.54, \mathrm{p} \leq 0.001\right)$; this is also supported by the weight of leg muscle ( $\mathrm{p} \leq 0.01$ ). These differences were much higher in $\mathrm{M}$ than in $\mathrm{F}$ mice in all shown variables in Table 1 (statistical analysis revealed some differences between male and female heavy mice $\left(\mathrm{F}_{1,56}=49.19, \mathrm{p} \leq 0.001\right.$; WIRTH-DZIECIOŁOWSKA et al., 2004). Muscle constitutes $42-47 \%$ of animal body weight, and due to their growth, the total protein content of the animal also increases. The percentage of protein does change during the experiment, being the lowest in $\mathrm{L}$ as compared to $\mathrm{K}$ and $\mathrm{C}$ mice. The higher protein/DNA ratio and lower DNA concentration in $\mathrm{K}$ mice as compared to $\mathrm{L}$ and $\mathrm{C}$ ones support the notion that the $\mathrm{K}$ mice have grater muscle maturity and physiologic maturity at a younger age. Similar findings heve been observed in genetically different lines of swine (HARBIDSON et al., 1976) and in lean versus obese 2.5 month old DurocxYorkshire swine (KRETCHMAR, 1994). The RNA:DNA ratio (the concentration of ribosomes per nucleus) in female mice was lower than in male, suggesting slower female muscle compositional maturity. This was also the case in the liver (Table 5). Because of the multinucleated state of the myotube in muscle, total DNA is not an acceptable measure of myotube number. Rather, total DNA/mg tissue allows comparisons of nuclei content among populations. This was the case in the long-term growth selected (over 40 generations) laboratory mice; this selection raised the number of nuclei in the muscles of about 30-39 \% and reduced nucleus/plasma ratio only in mice selected for protein growth (REHFELD and BÜNGER, 1990). Protein: $10^{3}$ DNA ratio, called „functional cell size” - FCS, is the imaginary volume of cytoplasm controlled by a single nucleus (CHEEK, 1985) and is a very good factor to estimate cell size. This ratio was different between $\mathrm{F}$ and $\mathrm{M}$ in each group, being higher in M mice. 60-80 \% of muscle DNA resides inside the muscle fibrils and it must be assumed that any changes in DNA content occurred proportionally inside and outside of muscle fibrils. Within a given muscle there are a different proportion between individual fibril types and the higher number of average fibrils (30.00-50.00 $\mu \mathrm{m}$ ) was found in $\mathrm{M}$ of $\mathrm{L}$ and $\mathrm{C}$ mice and this may affect its size and metabolism. Our results demonstrate quite marked changes between females and males (by $26.8 \%$ in $\mathrm{K}$, $6.2 \%$ in $\mathrm{L}$ and $36.8 \%$ in $\mathrm{C}$ ), being much higher in $\mathrm{M}$ groups, indicating the higher FSC in M mice. This is supported also by the RNA:DNA ratio - the concentration of 
ribosomes per nucleus - that was much higher in $\mathrm{M}$ than in $\mathrm{F}$ mice (by 31 \% in $\mathrm{K}, 18$ $\%$ in $\mathrm{L}$ and $39 \%$ in $\mathrm{C}$ mice, respectively). In another experiment with mice (ROSOCHACKI, 1989) the changes of protein: $10^{3} \mathrm{DNA}$ ratio were at about $60 \%$ affected by different nutritional conditions (different amount of protein, fat and carbohydrate in the diet). In experiment with female mice which were exposed to cold from 1 to 30 days, this ratio was the highest after 1 day of cold (being higher by $13 \%$ ) and was the same as in control after 30 days of cold (ROSOCHACKI and PIEKARZEWSKA, 1988).

The data from Table 2 suggest some potential differences in the proteolytic capacity of examined mice. The most changes were noticed in activities of CatD, PSCatD, AAA and LIA in L group of mice as compare to the $\mathrm{K}$ ones, being much higher in $\mathrm{F}$ as compare to $\mathrm{M}$ (in \%). This is in an agreement with the lower percent of bigger fibril diameter of muscles noticed in male mice as compared to female. The percent of fibrils between 50.00-70.00 $\mu \mathrm{m}$ was much higher in F (being about $30 \%$ in average) than in $\mathrm{M}$ (average about $17 \%$ ). This can be due to the relative rates of maturation and remodeling of muscle fibrils as measured activities increased as much as compared to control mice and were the ones of to degrade myofibrillar proteins. The increase of proteolytic activities to remodel the cells was also noticed in PLD muscle of chicken (ROSOCHACKI, 1985), when the hypertrophy was caused by the weight attached to the wing. Thus, the differences observed in the proteolytic capacity in mouse muscle, may be limited to the time frame investigated and therefor, should be viewed with caution.

The proteolytic pattern of changes is different between the liver and muscle and more pronounceable in the muscle. In the liver some differences between $\mathrm{F}$ and $\mathrm{M}$ mice were noticed. This may be due to the structure of cytoplasmic proteins, as the liver cell is diploid but muscle fibrils are multinucleated. The lowest CatD and PSCatD activities in the liver were observed in $C$ group of mice, being about (in average) $82 \%$ and $78 \%$ of that, estimated in $\mathrm{K}$ mice, respectively. This was also the case in the work of SCHMIDT et al. (2000) who found 30-50 \% lower activity in the liver of animals with high body gain, in comparison to the control ones. Also, LIA activity was lowered by about $12 \%$ as compare to $\mathrm{K}$ (which reflects asparagine cathepsin). It was supported by higher percent of AAA inhibition by leupeptin, suggesting a higher amount of this enzyme in the group of $\mathrm{C}$ animals. PIA activity (reflecting thiol cathepsins) was higher in $\mathrm{L}$ and $\mathrm{C}$ examined groups as compare to $\mathrm{K}$ ones, but the amount of these enzymes were lower as compare to K. This should mostly point out on the higher participation of thiol enzymes in the liver protein turnover. These results confirm the statement of SCHMIDT et al. (2000), that inhibition of proteolysis is an immediate mechanism in the induction of growth.

Also the proteolytic environment is different between leg muscle and the liver. In the liver, about $23 \%$ (in average in C animals) to $12 \%$ (in average in $\mathrm{K}$ ) of enzymes were of different origin than measured in our experiment. In the leg muscle, in the measured condition, the estimated lysosomal enzymes were the main ones (almost $90 \%$ in $\mathrm{K}$ and $98 \%$ in average in $\mathrm{L}$ and $\mathrm{C}$ animals). This suggests also different ways of protein catabolism in these tissues. The ratio of PSCatD/PIA was the highest in the muscle of $\mathrm{L}$ animals as compare to $\mathrm{K}$ or $\mathrm{C}$ mice, but in the liver, the lowest ratio was in $\mathrm{L}$ and $\mathrm{C}$ animals. This indicated about the higher participation of thiol proteinases in the liver of these mice as compare to $\mathrm{K}$ animals. 
An increased activity of proteolytic enzymes e.g. cathepsin could result from changes in cathepsin-cystatin interactions rather than gene expression. It was shown by HASSELGREN (1999), that an increased amount of mRNA is not directly correlated with the increase of protein breakdown rate. Therefore, it is not possible to explain muscle degradation only by increase or decrease in mRNA concentration. The level of proteolytic enzymes reflected by the sum of inhibitions by pepstatin and by leupeptin in AAA was higher by about $10 \%$ (in average from $\mathrm{F}$ and $\mathrm{M}$ animals) in $\mathrm{L}$ and $\mathrm{C}$ groups as compared to control ones. So, the level of aspartic and thiol enzymes was higher in the muscle of L and C mouse compared to K, and their activity were much higher only in L animals. That means, that proteolytic enzymes are more active in L mouse (also less total protein in the muscle). In the present experiment, the inhibition by leupeptin in leg muscle was about $45 \%$ higher in $\mathrm{C}$ group as compare to L mouse. This inhibition in isolated anterior and posterior latissimus dorsi chicken muscles was about $20.9 \%$ in control and $16.5 \%$ in hypertrophic ones (ROSOCHACKI, 1985). This suggests that the extent of enzymatic response to the catabolism of protein in mice is quite similar to chickens. Contrary to chicken, in the mice' muscles, aspartic and thiol proteinases play the major contribution in miofibrillar proteolysis.

The relevance of thiol cathepsins (mostly B and L) and cathepsin D in muscle to animal growth has yet to be elucidated. These enzymes play an important role in the degradation of sarcoplasmic and myofibrillar proteins (actin and myosin) and proteins released by others (for ex. calpains) proteinases. The calpains, which are regulated by calpastatin and $\mathrm{Ca}^{2+}$, may initiate the turnover of myofibril in muscle (GOLL et al., 1998); calpastatin plays an important role in regulating muscle growth and skeletal muscle protein turnover. The magnitude of muscle protein turnover depends on a multitude of factors: the effect of exogenous glucose (KOŁĄTAJ et al.; 1998) or glutathione supplementation to the diet (ŚLIWA-JÓŹWIK et al., 2002), which cause the changes in activities of some lysosomal enzymes. Animal growth rate is one of the most important and can be modulated by nutrition, eg. food restriction during a certain period followed by re-feeding provoking compensating growth (MILLWARD et al., 1980, 1981) or breeding and environment (FIEDLER et al., 1998). In this experiment, the selection for low and high body weight over 108 generation was done being the only factor that influenced the growth of animals (WIRTH-DZIĘCIOŁOWSKA et al., 1997, 2000). The histological evaluation of gastrocnemius muscles showed, that in older male mice there is about $36 \%$ of muscle fibrils of 30.00-39.99 $\mu \mathrm{m}$ in both groups. It is interesting to point out, that in males of $\mathrm{L}$ line the fibrils of $40-49.99 \mu \mathrm{m}$ are present in $25 \%$ at this age as they were absent in the 3 weeks old mice. The fibrils of over $70 \mu \mathrm{m}$ have appeared in 3 months old male $\mathrm{L}$ mice, and there were not fibrils of $19.99 \mu \mathrm{m}$. Fibrils of 20.00-49.99 $\mu \mathrm{m}$ were the only ones in younger (3 weeks) animals. The fibrils between 20.00-29.99 $\mu \mathrm{m}$ accounted for $84 \%$ of the muscle cells at this age. In females, the changes in the diameters of fibrils were much more variable. The size of fibrils was between $20.00-80.00 \mu \mathrm{m}$. In both lines of mice the fibrils of 30.00-39.99 $\mu \mathrm{m}$ accounted for $27 \%$ and $12 \%$ in lines L and C, respectively; the fibrils of $40.00-49.99 \mu \mathrm{m}$ were present in $34 \%$ and $28 \%$, but $60.00-69.99 \mu \mathrm{m}$ fibrils were in $10 \%$ and $7 \%$, respectively. Also FIEDLER et al., (1998) found out that intensive muscle growth in domestic pigs was caused by increased fibril size and fibril number. Similar data were shown by (REHFELD and BÜNGER, 1990), who found a marked differences in muscle fibril thickness and fibril number in $M$. rectus femoris and extensor digitorum longus between mice selected for protein growth and those 
selected for index comprising body weight and treadmill performance over 40 generations. They also pointed out that the fibril type composition remained unchanged even under such long selection.

From the ratio of PSCatD/PIA it is obvious, that cathepsin D plays much minor role in degradation of leg muscle proteins in $\mathrm{C}$ as compared to $\mathrm{L}$ and $\mathrm{K}$ mice. The remodeling of muscle fiber was much less done by CatD in $\mathrm{K}$ and $\mathrm{C}$ then in $\mathrm{L}$ mice. This is the first evidence supported by the histological evaluations of different ways of tissue remodeling in animal selected over 108 generations for low and high body weight. The higher participation of CatD in the remodeling of the muscle was found in mice selected for low weight, but in animals selected for higher body weight, the participation of thiol proteinases was much more evident.

Therefore, this study indicates the need for further, more precise investigations on protein metabolism, regarding proteolytic variables in the growing muscle to help understand the mechanisms of remodeling of muscle fibrils and muscle and animal growth. Additionally, the proteinases were assayed in vitro, so that theirs potential capacity was measured, which does not necessarily represent their physiological activity. However, in particular the changes in proteolytic variables, may prove useful in understanding the mechanisms of muscle growth and its remodeling. It appears that differently selected lines of mice can be useful model animals for studying skeletal muscle protein turnover and remodeling of the tissue. These results indicate faster turnover of proteins in the group of mice selected for low weight over 108 generations as compared to those selected for the high weight and control mice.

\section{References}

BELCASTRO, A.N.; SHEWCHUK, L.D.; RAJ, D.A.: CHEEK, D. B.

Exercise induced muscle injury: a calpain hypothesis. Mol. Cell. Biochem. 179 (1988), 135-145

The control of cell mass and replication. The DNA unit - a personal 20-year study. Early Human Develop. 12 (1985), 211-239

FIEDLER, I.; REHFELD, CH.; ALBRECHT, E.; HENNING, M

Histophysiological features of skeletal muscle and adrenal glands in wild-type and domestic pigs during growth. Arch. Tierz., Dummerstorf 41 (1998), 489-495

GOLDSPINK, D.F.; LEWIS, S. E.M.:

Age and activity-related changes in three proteinase enzymes of rat skeletal muscle. Biochem. J. 230 (1985), 833-836

GOLL, D.E.; THOMPSON, V.F.; TAYLOR, R.G.; OUALI, A.:

The calpain system and skeletal muscle growth. J. Anim. Sci. 78 (1998), 503-512

GRANT, A.L.; HELFERICH, W.C.:

An overview of growth. In "Growth regulation in farm animals Advances in Meat Research" (Edited by PEARSON, A.M.; DUSTON, T.R.), Elsevier, London, New York (1991), (Vol. 7) 1-16

HARBISDON, S.A.; GOLL, D.E.; PARISH, JR., F.C.:

Muscle growth in two genetically different lines of swine. Growth, 40, (1976). 253-283

HASSELGREN, P.O.:

Glucocorticoids and muscle catabolism. Curr. Op. Clin. Nutr. Metab. Care 2 (1999), 201-205

JOHARI, S.; MAEDA, Y.; OKAMOTO, S.; HASHIGUCHI, T.:

Comparison of calpain and calpastatin activities in skeletal muscle of broiler and layer chickens. Br. Poultry Sci. 34 (1993), 819-824

KOŁĄTAJ, A.; SOMMER, A.; WITEK, B; NITRAY, J.; FLAK, P.:

The effect of exogenous glucose on the activity of lysosomal enzymes, the glucose and insulin concentration in the blood plasma of young bulls. Arch. Tierz., Dummerstorf 41 (1998), 371-377

KRETCHMAR, D.H.; KOOHMARAIE, M.; MERSMANN, H.J.: Comparison of proteolytic variables in lean and obese strain of pig at the ages of 2.5 and 7 months. Lab. Anim. Sci. 44 (1994), 38

KÜCHENMEISTER, U.; KUHN, G.: 
Regulation of intracellular Ca 2+ concentration and meet quality in pigs. Arch. Tierz., Dummerstorf $\mathbf{4 6}$ (2003), 445-454

KÜCHENMEISTER, U.; LANGHAMMER, M.; RENNE, U.; NÜRNBERG, G.; ENDER, K.: Effects of exercise on sarcoplasmic reticulum Ca 2+ transport in muscle of mouse lines long-term selected for different performance traits. Arch. Tierz., Dummerstorf 44 (2001), 441-450

LAURENT, G.J.; SPARROW, M.P.; BATES, P.C.; MILLWARD, D.J.: Turnover of muscle protein in the fowl (Gallus domesticus). Rates of protein synthesis in fast and slow skeletal, cardiac and smooth muscle of adult fowl. Biochem. J. 176 (1978), 407-417

LOWRY, O.H.; ROSEBROUGH, N.J.; FARR, A.L.; RANDALL, R.J.: Protein measurement with folin phenol reagent. J. Biol. Chem. 193 (1951), 265-275

MIKAMI, M.; WHITTING, A.H.; TAYLOR, M.J.; MACIEWICZ R.A.; ETHERINGTON, D.J.: Degradation of myofibrils from rabbit, chicken and beef by cathepsin L and lysosomal lysates. Meat Sci. 21 (1987), 81-97

MILLWARD, D.J.; BATES, P.C.; BROWN, J.G.; ROSOCHACKI, S.J.; RENNIE, M.J.: Protein degradation and the regulation of protein balance in muscle. In "Protein degradation in health and disease”, CIBA Foundation 75, (1980), 307-329

MILLWARD, D.J.; BATES, P.C.; ROSOCHACKI, S.J.:

The extent and nature of protein degradation in the tissues during development. Reprod. Nutr. Dev. 21 (1981), 265-277

MUNRO, H.N.; FLECK, A.:

The determination of nucleic acids. Methods in Biochemical Analysis 14 (1966), 113-176

REHFELD, CH.; BÜNGER, L.:

Auswirkungen einer Langzeitselektion von Labormäusen auf Merkmale des Muskelwachstums und der Muskelstruktur. Arch. Tierz., Dummerstorf 33 (1990), 507-516

ROSOCHACKI, S.J.:

Changes in cathepsin D, proteolytic activity and RNA and DNA content in the anterior and posterior lattissimus dorsi muscle of the adult fowl as affected by the induced hypertrophy. Arch. Geflügelk. 49 (1985), 81-90

ROSOCHACKI, S.J.:

Changes in cathepsin D, acid autolytic activity, RNA, DNA in skeletal muscle and liver of mouse kept on high protein, carbohydrate and lipides diets. Acta Physiol. Polonica 40 (1989), 363-373

ROSOCHACKI, S.J.; PIEKARZEWSKA, A.B.:

Changes in protein and carbohydrate metabolism in the liver and skeletal muscle of mice exposed to cold.

Anim. Sci. Pap. Rep. 4 (1988), 133-147

SCHMIDT, M.; KROL, T.; RENNE, U.; PANICKE, L.:

Proteolytische Aktivität der lyosomalen Enzyme in der Leber wachsender Mäuse. Arch. Tierz., Dummerstorf 43 (2000), 363-374

ŚLIWA-JÓŹWIK, A.; JÓŹWIK, A.; KOŁĄTAJ, A.:

Influence of exogenous glutathione (GSH), as stressfactor, on the activity of lysosome enzymes in some organs of mice. Arch. Tierz., Dummerstorf 45 (2002), 307-314

THOMPSON, M.G.; PALMER, R.M.:

Signaling pathways regulating protein turnover in skeletal muscle. Cell Signaling 10 (1998), 1-11

WIRTH-DZIĘCIOŁOWSKA, E.; CZUMIŃSKA K.:

Longevity and aging of mice from lines divergently selected for body weight for over 90 generations. Biogereont. 1 (2000), 169-176

WIRTH-DZIĘCIOŁOWSKA, E.; CZUMIŃSKA K.; REKLEWSKA B.; KATKIEWICZ, M.:

Life time reproduction performance and functional changes in reproductive organs of mice selected divergently for body weight. Anim. Sci. Pap. Rep. 14 (1996), 187

WIRTH-DZIĘCIOŁOWSKA, E.; FABIAŃSKA M.; KARASZEWSKA J.; CZERWIŃSKA, K.: Dynamics of growth and changes occurring with age in mice selected for body weight for 90 generations on the $21^{\text {st }}$ day of life. Annales of Warsaw Agricultural University-SGGW Anim. Sci. 33 (1997), 55-67

WIRTH-DZIECIOŁOWSKA, E.; GAJEWSKA, M.; ROSOCHACKI, S.J.; ŻMUDA, M.; ZIMNOWSKA, M.: Differential growth of skeletal muscle in lines of mice selected over 108 generation for low and high body weight. (2004), in press 
Authors' addresses

Prof. Dr. hab. STANISŁAW J. ROSOCHACKI*, Polish Academy of Sciences, Institute of Genetics and Animal Breeding, Jastrzębiec, 05-552 Wólka Kosowska, Poland Białystok Technical University, Chair of Sanitary Biology and Biotechnology 45e Wiejska str

15-351 BIAŁYSTOK, POLAND

E-mail: S.Rosochacki@ighz.pl

Dr. hab. ELŻBIETA WIRTH-DZIĘCIOŁOWSKA, Warsaw Agricultural University, Department of Genetics and Animal Breeding

8 Ciszewskiego str,

02-786 WARSZAWA, POLAND

E-mail: ewd@o2.pl

Dr MAŁGORZATA ZIMOWSKA, Warsaw University, Faculty of Biology, Institute of Zoology, Department of Cytology

1 Miecznikowa str,

02-096 WARSZAWA, POLAND

e-mail:mzimowska@biol.uw.edu.pl

Dr MAGDA GAJEWSKA, Museum and Institute of Zoology,

64 Wilcza str,

00-679 WARSZAWA, POLAND

e-mail: mgajewska@miiz.waw.pl.

Dr TOMASZ SAKOWSKI, Mgr JAROSŁAW POŁOSZYNOWICZ, Mgr EDYTA JUSZCZUK-KUBIAK

Polish Academy of Sciences, Institute of Genetics and Animal Breeding, Jastrzębiec, 05-552 WÓLKA KOSOWSKA, POLAND

E-mail: t.sakowski@ighz.pl

E-mail: e.kubiak@ighz.pl

*Corresponding author 